Int. J. Dev. Biol. 61: 793-800 (2017)

doi: $10.1387 / \mathrm{ijdb} .170259 \mathrm{ik}$

\title{
Novel polyclonal antibodies as a useful tool for expression studies in amphioxus embryos
}

\author{
MATTEO BOZZO\#, JIRI PERGNER\#, ZBYNEK KOZMIK and IRYNA KOZMIKOVA* \\ Laboratory of Transcriptional Regulation, Institute of Molecular Genetics of the Czech Academy of Sciences, \\ Prague, Czech Republic,
}

\begin{abstract}
Cephalochordates, commonly called amphioxus or lancelets, are widely regarded as a useful proxy for the chordate ancestor. In recent decades, expression patterns of important developmental genes have been used extensively to infer homologies between cephalochordate and vertebrate embryos. Such comparisons provided important insight into cephalochordate biology and the origin of vertebrate traits. Most of the developmental expression data are collected using whole-mount in situ hybridization that allows the distributions of specific transcripts to be detected in fixed embryos. Here, we describe an experimental pipeline for production of small amounts of functional antibodies directed against amphioxus antigens for use in immunohistochemical labelling. In this pilot study, we generated antibodies against $\beta$-catenin and the transcription factors FoxA, Lhx1, Lhx3 and Pax6. We demonstrate the usefulness of antibodies by performing immunostainings on fixed specimens of $B$. lanceolatum and $B$. floridae. We anticipate that amphioxus-specific antibodies will provide a useful tool for high-resolution labelling of individual cells within the embryo and for determining the subcellular localization of the corresponding proteins.
\end{abstract}

KEY WORDS: Branchiostoma, amphioxus, antibody, expression pattern

Cephalochordates, commonly called amphioxus or lancelets, are regarded as a key animal group for understanding the origin of vertebrates, and a useful proxy to the ancestral chordate condition. This position has recently been affirmed especially thanks to the access to genome sequence data (Holland et al., 2008; Huang et al., 2014; Putnam et al., 2008), introduction of novel techniques (Acemel et al., 2016; Kozmikova and Kozmik, 2015; Li et al., 2017; Yue et al., 2016), and establishment of amphioxus as a model species for evolutionary developmental studies (for review see Bertrand and Escriva (2011)). Cephalochordates include three genera, namely Branchiostoma, Asymmetron and Epigonychtys. The phylogenetic relationships within the extant amphioxus lineage were recently investigated providing divergence time estimates and suggesting a rather recent diversification (Igawa et al., 2017). For example, the estimated divergence times among species within the Branchiostoma genus (22.6 +/-2.3 Mya for B. lanceolatum- B. floridae split) are comparable to those among rodents belonging to Muridae family (such as mouse and rat). Close phylogenetic relationship is mirrored by a high degree of coding sequence identity (Holland et al., 2008; Huang et al., 2014; Putnam et al., 2008; Yue et al., 2014) and by evidence for stasis in developmental expression patterns (Somorjai et al., 2008).

Expression patterns of important developmental genes have been used extensively to infer homologies between cephalochordate and vertebrate embryos. Such comparisons provided important insight into cephalochordate biology and the origin of vertebrate traits. Most of the expression data were collected using whole mount in situ hybridization (WMISH) that allows the distributions of specific transcripts to be detected in fixed embryos. A plausible alternative for analysis of gene expression is based on protein detection by immunohistochemical staining in sections or whole mount preparations. In principle, immunostaining is easy to perform, provided that there are antibodies which specifically recognize the antigen of interest. Unfortunately, the current antibody repertoire for non-model invertebrates such as amphioxus is

Abbreviations used in this paper: $\mathrm{TH}$, tyrosine hydroxylase; WMISH, whole mount in situ hybridization.

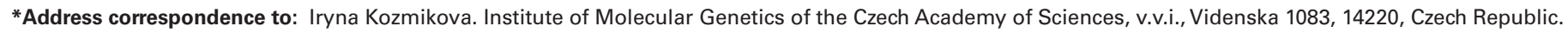
Tel: +420 241062110. E-mail: kozmikova@img.cas.cz \#Note:The indicated authors contributed equally to this work.
}

Supplementary Material (2 figures +1 table) for this paper is available at: http://dx.doi.org/10.1387/ijdb.170259i 
rather limited. Both monoclonal and polyclonal antibodies can be made against a protein of interest. Polyclonal antibodies have the advantage of typically being of higher affinity, whereas the monoclonal antibodies have higher specificity since they recognize a single epitope. A clear disadvantage of polyclonal antibodies is the fact that they are a non-renewable resource. On the other hand, monoclonal antibodies are costly and are not within the reach of a typical lab working in the area of evolutionary developmental biology. Commercially available antibodies produced for vertebrate research can in principle be used if directed against a highly conserved epitope shared by vertebrate and amphioxus protein. Currently, only antibodies against acetylated tubulin are routinely used (Le Petillon et al., 2017; Lu et al., 2012; Soukup et al., 2015; Vopalensky et al., 2012). A fairly small number of antibodies (all polyclonal) has so far been generated that specifically recognize amphioxus proteins in developing embryos (Vopalensky et al., 2012; Wu et al., 2011).

Here, we describe an experimental pipeline established for the production of small amounts of functional antibodies directed against amphioxus antigens. The procedure is based on cloning of cDNA fragments of the corresponding protein into an expression vector allowing production and hexa-histidine-tagged mediated purification of protein from $E$. colilysates followed by immunization of mice to obtain polyclonal antibodies. Antibodies recognizing five $B$. floridae proteins ( $\beta$-catenin, FoxA, Lhx1, Lhx3 and Pax6) were generated. We demonstrate the usefulness of antibodies generated in this way by performing immunostainings on fixed embryo specimens of $B$. lanceolatum, B. floridae and A. lucayanum.

\section{Results and Discussion}

We set out a pilot project to develop antibodies against a panel of amphioxus regulatory proteins. Our main aim was to design and evaluate a generalized scheme of antibody production that could routinely be used in the lab for generation of functional antibodies at a reasonable cost. We opted primarily to create polyclonal antibodies due to the simplicity of production, modest cost and higher chance to cross-react with protein of interest in different amphioxus species. We chose mice as the host since they represent a cost-effective alternative to the more widely used rabbits. The amount of serum obtained is relatively small (200-400 $\mu l$ per mouse) but appears to be sufficient to perform hundreds of immunostainings that are clearly enough to accomplish a focused study. It is of note that smaller amounts of purified antigen are necessary for immunization of mice compared to rabbits. Choice of mice as hosts for antibody production allows us to routinely immunize three mice with low animal cost. In the cases described in this study at least one functional antibody was obtained by immunizing three mice. However, if necessary, more mice can be immunized with minimal additional costs to increase the chance of obtaining a functional antibody and to overcome differences in immunological responses of individual mice. Although short synthetic peptides (15 to 20 amino acids) are often used for immunization, the functionality of the resulting antibodies is highly variable. Production and purification of fusion proteins encoding portions of an antigen is labor intensive. However, the use of longer peptide sequences from the antigen should in principle increase the chance of possessing an immunogenic epitope. When choosing $B$. floridae peptide sequences for immunization in our pilot study, we avoided sequences highly conserved among Metazoa, such as DNA-binding domains. In addition, in order to obtain antibody specific for a given protein, sequences with a high degree of identity among possible $B$.floridae paralogues were also omitted.

To generate antigens for immunization we expressed part of the selected proteins (ranging from 130 to 177 amino acids) in $E$. coli with hexa-histidine tags. After purification under denaturing conditions, the antigens were injected into mice for the generation of polyclonal antibodies. We standardized our procedure to

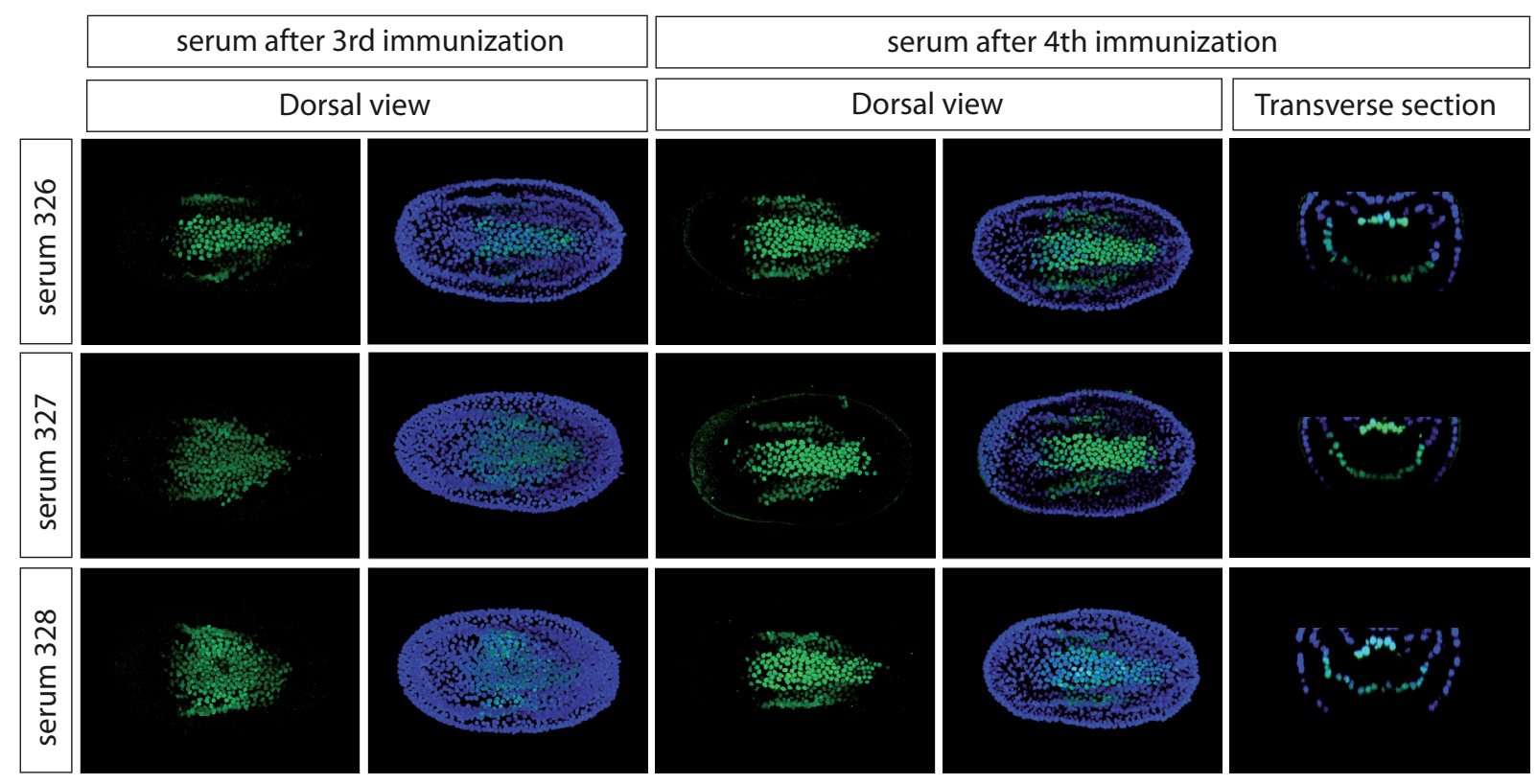

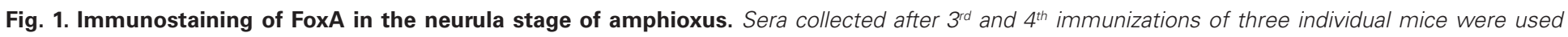

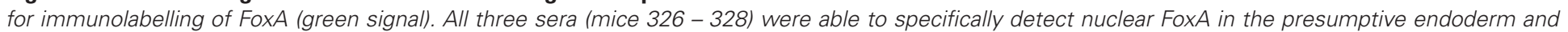

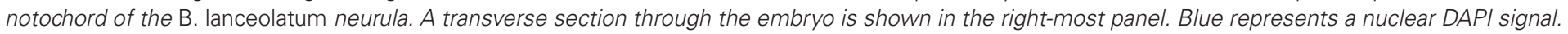


Fig. 2. Immunostaining of Lhx1, Lhx3 and Pax6 in amphioxus larvae. Larvae of $\mathrm{B}$. lanceolatum were immunostained with sera $249(\mathbf{A}), 330(\mathbf{B}, \mathbf{C})$, and 925 (D). Lhx1 (A) and $L h \times 3$ (B,C) are detected in cells of the dorsal nerve cord (green signal). In addition, nuclear signal for $L h x 3$ is present in the preoral pit (B). A composite of a bright field and fluorescent image is shown in (B). (D) The red nuclear signal represents Pax6 expression in the amphioxus primarymotor centre (yellow arrowheads mark three pairs of Pax6-positive neurons) and in the frontal eye (white arrow). The conspicuous ectodermal signal represents unspecific labelling. Blue represents nuclear DAPI signal.
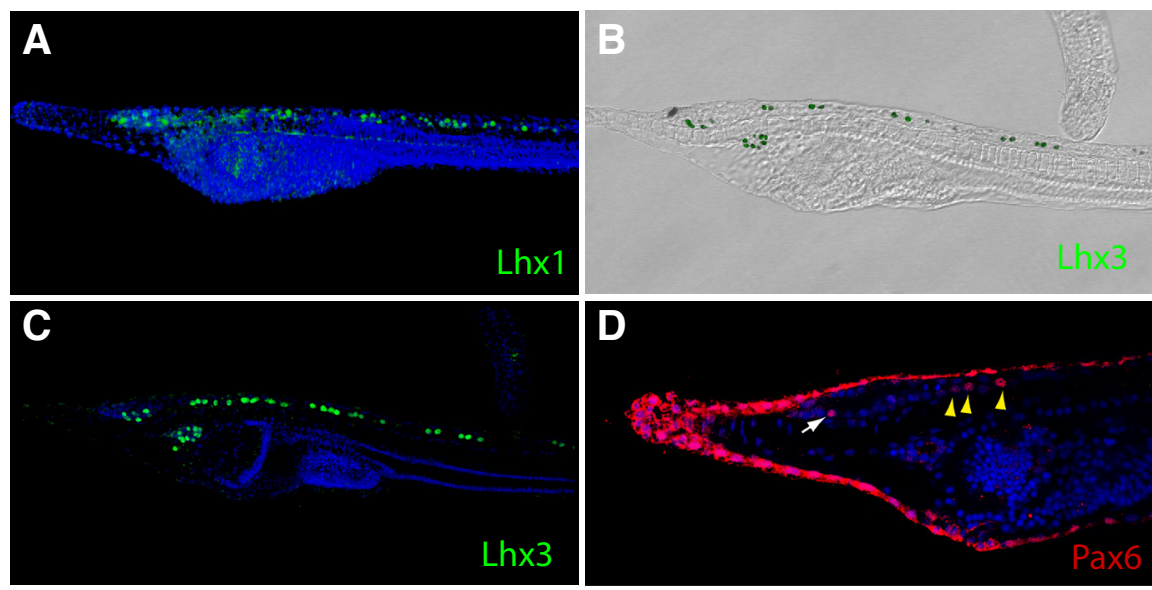

routinely perform a series of four immunizations. A sample of the serum was taken from the tail vein after the $3^{\text {rd }}$ immunization to monitor efficacy and specificity of the serum by immunostaining. Table 1 provides a summary of amphioxus-specific antibodies we produced. Antibodies recognizing five $B$. floridae proteins, namely FoxA, Lhx1, Lhx3, Pax6 and $\beta$-catenin, were generated in the current study. Below we describe each reagent that we produced and characterized by immunostaining of appropriate stages of amphioxus embryos and larvae.

The FoxA gene (alternative name Hnf3) encodes a forkhead transcription factor. Amphioxus has two HNF3class genes, named AmHNF3-1 (FoxAa) and AmHNF3-2 (FoxAb), with apparently identical expression pattern in the presumed organizer, endoderm, and notochord at the neurula stage (Shimeld, 1997). Molecular phylogenetic analysis revealed that these paralogues derive from an independent duplication in the cephalochordate lineage
(Shimeld, 1997). Antibodies directed against FoxA were made by immunizing mice with a C-terminal part of $B$. floridae FoxAa. As shown in Fig.1, all three sera 326 - 328 were able to specifically detect nuclear FoxA in presumptive endoderm and notochord of $B$. lanceolatum neurula, in a pattern matching the one obtained by in situ hybridization (Shimeld, 1997; Terazawa and Satoh, 1997). Sera obtained after the $3^{\text {rd }}$ immunization showed high specificity and good signal to noise ratio. However, a stronger signal was detected using sera $326-328$ collected after the $4^{\text {th }}$ immunization (Fig. 1). A similar trend regarding $3^{\text {rd }}$ and $4^{\text {th }}$ sera was observed for antibodies generated against other antigens as well.

Amphioxus Lhx1 (Lim1) encodes a LIM-homeobox gene orthologous to vertebrate $L h x 1$ and $L h x 5$. During amphioxus development, $L h x 1$ is first detected in the ectoderm of the blastula (Langeland et al., 2006). Then, in the gastrula, in addition to the ectoderm $L h x 1$ expression appears in the mesendoderm just within the dorsal lip

TABLE 1

SUMMARY OF AMPHIOXUS-SPECIFIC ANTIBODIES DESCRIBED IN THIS STUDY

\begin{tabular}{|c|c|c|c|c|c|c|}
\hline Gene & $\begin{array}{l}\text { Antibody name } \\
\text { (serum number) }\end{array}$ & $\begin{array}{l}\text { Efficacy of the antibody } \\
\text { in staining }\end{array}$ & Species tested & $\begin{array}{c}\text { Fixation } \\
\text { and storage }\end{array}$ & Comment & Reference \\
\hline$\beta$-catenin & 097 & - & $B I$ & $a$ & Nonspecific staining of most nuclei. & This study \\
\hline$\beta$-catenin & 393 & ++ & $B I$ & $a, b$ & Functional on ethanol-stored samples. & This study \\
\hline$\beta$-catenin & 394 & ++ & $B I$ & a & & This study \\
\hline FoxA & 326 & +++ & $B I, B f, A l$ & a & & This study \\
\hline FoxA & 327 & +++ & $B l, B f$ & $a$ & & This study \\
\hline FoxA & 328 & ++ & $B l, B f$ & $a$ & & This study \\
\hline Lhx1 & 249 & +++ & $B l, B f$ & $a, b, c, d$ & $\begin{array}{l}\text { Functional on ethanol-stored samples albeit with slightly worse } \\
\text { signal/noise ratio. }\end{array}$ & This study \\
\hline Lhx1 & 250 & + & $B l, B f$ & $a, b, c, d$ & Signal undetectable in ethanol-stored samples. & This study \\
\hline Lhx1 & 325 & ++ & $B l, B f$ & $a, b, c, d$ & $\begin{array}{l}\text { Diffused nonspecific staining of epidermal nuclei, together with } \\
\text { specific signal in the neural tube. Nonspecific signal is dominant in } \\
\text { ethanol-stored samples. }\end{array}$ & This study \\
\hline Lhx3 & 329 & ++ & $B l, B f$ & $a$ & & This study \\
\hline Lhx3 & 330 & +++ & $B l, B f$ & a & & This study \\
\hline Lhx3 & 331 & + & $B l, B f$ & $a$ & & This study \\
\hline Pax6 & 925 & ++ & $B f, B l, A l$ & a & & This study \\
\hline Pax6 & 926 & - & $B f, B l, A l$ & $a$ & & This study \\
\hline Pax6 & 927 & + & $B f, B I, A l$ & a & & This study \\
\hline Otx & 72 & +++ & $B f, B I, A l$ & $a$ & & Vopalensky et al., 2012 \\
\hline Ops3 & 52 & + & $B f, B I$ & $a$ & Non-functional for B. lanceolatum & Vopalensky et al., 2012 \\
\hline
\end{tabular}

Abbreviiations: +++, easily detected; ++, detected; +, detectable; -, not detected; Bf, Branchiostoma floridae, Bl, Branchiostoma lanceolatum, Al, Asymmetron lucayanum.

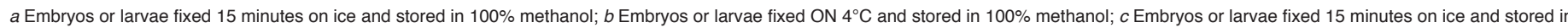
$70 \%$ ethanol; $d$ Embryos or larvae fixed $\mathrm{ON} 4^{\circ} \mathrm{C}$ and stored in $70 \%$ ethanol. 
of the blastopore. By the mid-neurula stage $L h x 1$ is expressed in the anterior part of the central nervous system, in the hindgut, in Hatschek's right diverticulum, and in the wall of the first somite on the left side (Langeland et al., 2006). At the larval stage, Lhx1 expression remains in lateral and ventral cells along the anterior third of the dorsal nerve cord, in Hatschek's nephridium, in the wall of the rostral coelom, in the epidermis of the upper lip, and in mesoderm cells near the opening of the second gill slit (Langeland et al., 2006). Antibodies directed against amphioxus Lhx1 were made by immunizing mice with a C-terminal part of $B$. floridae protein. We tested three anti-Lhx1 antibodies (sera 249, 250 and 324) on amphioxus larvae and obtained nuclear staining in cells of the dorsal nerve cord (Fig. 2A, Supplementary Fig. S1A), matching previously described expression domain of the gene (Langeland et al., 2006). Notable differences were observed for the three sera, with the best signal/noise ratio obtained for serum 249 (Supplementary Fig. S1A, Table S1).

The amphioxus $L h x 3$ gene encodes a LIM-homeobox gene. Its expression was studied in $B$. belcheri by WMISH (Wang et al., 2002). Expression of Bblhx3 first appeared in the vegetal and future dorsal side of the gastrula and became restricted to the endoderm during gastrulation. At the neurula and early larva
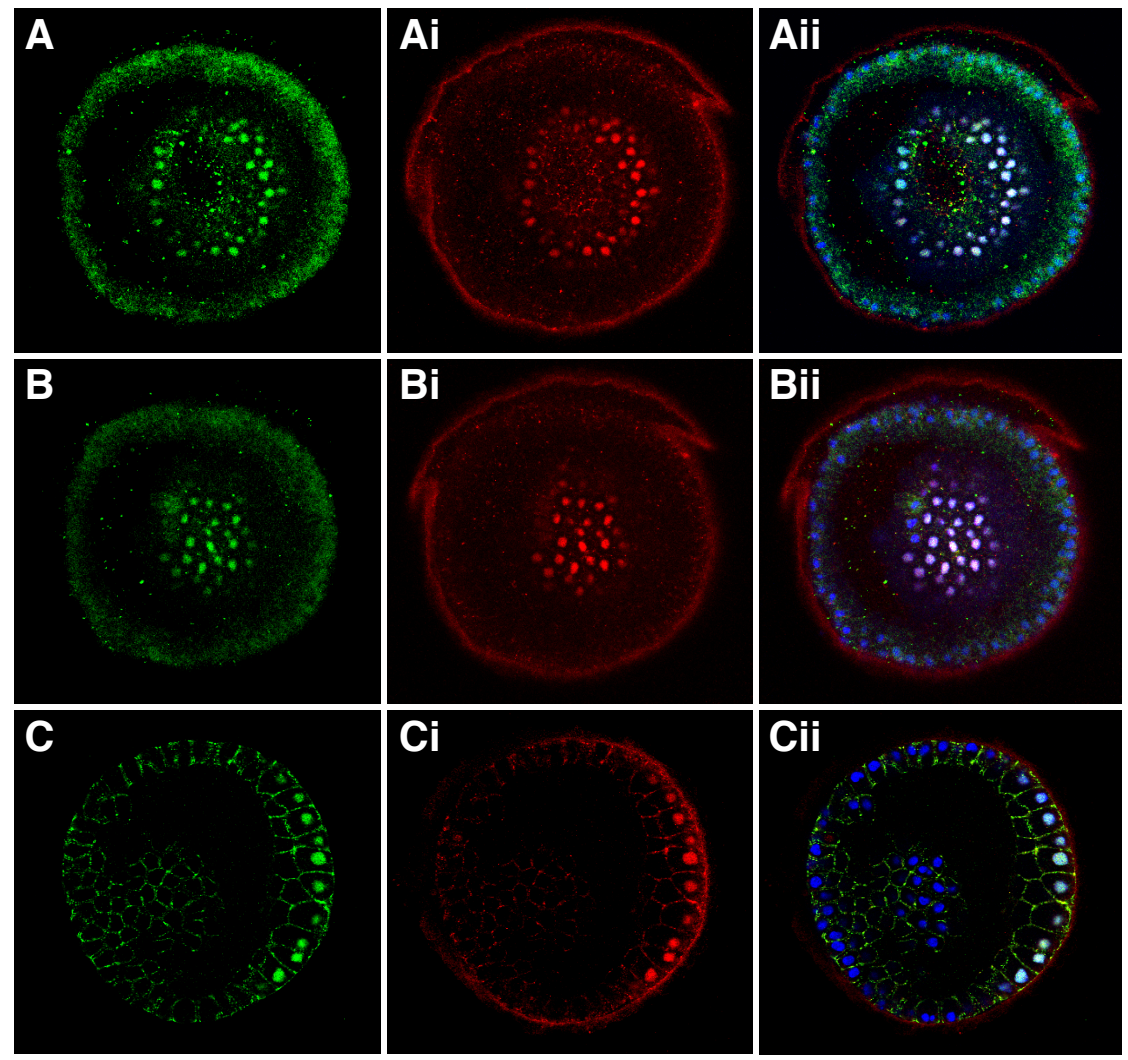

Fig. 3. Double immunostaining of $\beta$-catenin with amphioxus-specific and commercially available cross-reacting antibodies. (A,B,C) The signal of amphioxus-specific $\beta$-catenin antibody; (Ai, Bi, Ci) the signal of commercial anti-human $\beta$-catenin antibody (Sigma C2206). (Aii, Bii, Cii) Overlapping signals of DAPI (blue), amphioxus-specific (green signal) and commercial anti-human antibody (red signal). (A-Aii, B-Bii) Two z-stacks at different positions of the same embryo at mid-gastrula stage; optical z-sectioning was taken from a blastopore view. (A-Bii) $\beta$-catenin is detected in the mesendoderm. (C-Cii) A z-stack of the embryo at the late blastula stage. The embryo in (A-Bii) was stained with serum 393, whereas the embryo in (C-Cii) was with serum 394. stage, Bblhx3 was expressed in the developing neural tube, the notochord and preoral pit. We generated three antibodies (sera three antibodies detected Lhx3 in dorsally located cells of the cord and in the preoral pit of B. lanceolatum larvae (Fig. , Supplementary Fig. S1B), i.e. in areas characteristic for As in the sere observed for the three sera with the best signaise

(Supplementary Fig. S1B, Table S1). a mex6 encodes a paired and homeobox gene which constitutes et al., 2007). Pax6 is expressed in the anterior ectoderm from the early neurula stage until the early larval stages (Glardon et al., 1998). Expression is also detectable in Hatschek's left diverticulum as it forms the preoral ciliated pit. Regional expression in the anterior neural plate of early embryos continues later in the cerebral vesicle, most conspicuously in the lamellar body, in some cells of the frontal eye and in the primary motor center (Glardon etal., 1998; Vopalensky et al., 2012). We have previously generated antibodies specifically recognizing $B$. floridae Pax6 by immunizing rabbits with a C-terminal part of the corresponding protein (Vopalensky et al., 2012). Here, we used the same antigen to immunize mice in order to produce mouse polyclonal antibodies (sera 925, 926 and 927). Serum 925 was the most efficient one in labelling Row 1 cells of the frontal eye and cells of the primary motor center whereas serum 926 did not yield a positive signal (Fig. 2D, Supplementary Fig. S1C). In addition to specific labeling of individual neurons all Pax6 sera produced a very conspicuous (unspecific) ectodermal signal (Fig. 2D; see also Figs. 4C, 5B).

One of the hallmarks of canonical Wnt signaling activation is the nuclear accumulation of $\beta$-catenin, which interacts with Tcf/Lef family members to activate transcription of target genes. Thus, monitoring the distribution of nuclear $\beta$ catenin in the cells of the embryo permits the detection of regions in which the canonical Wnt signaling is active. Indeed, antibody labeling with immunohistochemical detection of $\beta$-catenin in $B$. floridae and $B$. belcheri embryos has previously been performed (Holland et al., 2005; Yasui et al., 2002). Surprisingly, the two studies demonstrated inconsistent differences in the distribution of nuclear $\beta$-catenin during early development in these two species. This could be due to the use of distinct antibody reagents derived against $\beta$-catenin of vertebrates (chicken and human) (Yasui et al., 2002) or sea urchin (Holland et al., 2005). We generated three antibodies (sera 097, 393, and 394) directed against amphioxus $\beta$-catenin by immunizing mice with a $\mathrm{C}$-terminal part of $B$. floridae protein. To check the specificity of individual sera and to validate previously used commercially available anti-human $\beta$-catenin antibody (Yasui et al., 2002) we performed double 


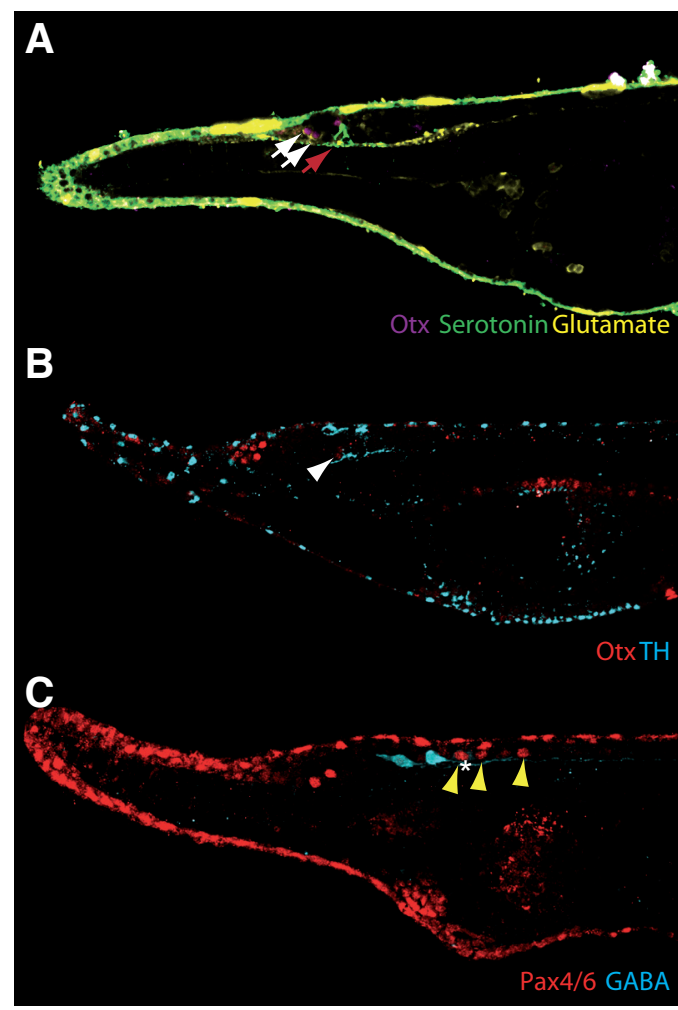

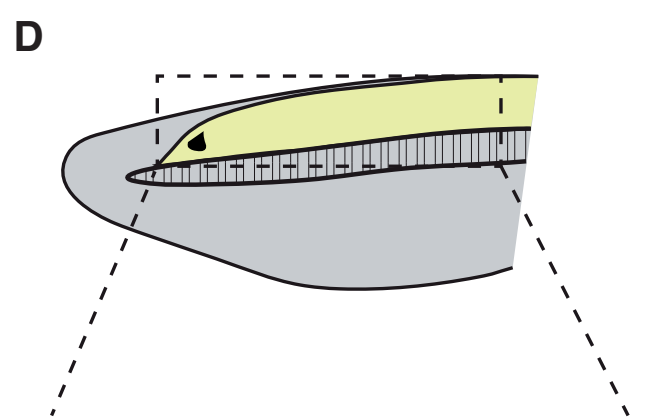

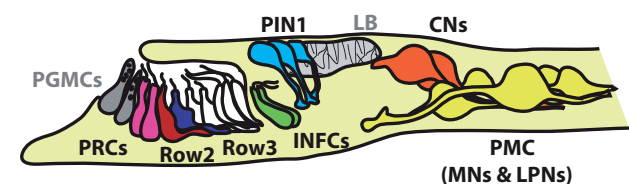

PRCs - Otx; Glutamate

Row2 - Serotonin

Row3 - Glutamate

INFCs - Otx

PIN1 - TH

Fig. 4. High-resolution detection of specific neurons in the cerebral vesicle by double immunostaining with amphioxus-specific and commercial antibodies. Amphioxus-specific antibodies were used to localize neuronal populations of interest and commercial antibodies were used to localize specific neuronal populations in the cerebral vesicle of $\mathrm{B}$. lanceolatum larvae. (A) Co-staining of B. lanceolatum larvae with mouse polyclonal antibody generated against amphioxus Otx and commercial polyclonal antibodies against neurotransmitters serotonin (raised in goat) and glutamate (raised in rabbit). White arrows mark Row1 cells of the frontal eye (Otx positive). The red arrow points to Row2 cells (serotonin positive). Glutamate serves as a neurotransmitter in Row 1 cells and Row 3 cells (positive signal posterior to Row2 cells). (B) Otx was used to mark infundibular cells (white arrowhead). Projections of tyrosine hydroxylase (TH)-positive neurons can be traced from the dorsolateral region of the cerebral vesicle to infundibular organ. (C) Yellow arrowheads mark the Pax6-positive three pairs of neurons in the amphioxus primary motor centre. The first pair of neurons is GABA positive. Note, that two other pairs of GABA-positive neurons (the so-called commissural neurons) were stained more anteriorly. The conspicuous ectodermal signal represents unspecific labelling. (D) Schematic diagram of the anterior part of amphioxus neural tube indicating labelling of individual neuronal populations in cerebral vesicle. Cells populations stained in A-C are highlighted by colors and described by black letters. Other important landmarks are depicted and described in grey. PGMCs - pigment cells of the frontal eye; PRCs - photoreceptors cells of the frontal eye; Row2 - so called "Row2 cells" of the frontal eye (potential visual projecting interneurons); Row3 - so called "Row3 cells" of the frontal eye (potential projecting interneurons); INFCs - infundibular cells (possible homolog of vertebrate balance organ); PIN1 - type 1 parainfundibular neurons; LB - lamellar body (possible homolog of vertebrate pineal gland); CNs - commissural neurons (possibly involved in regulation of amphioxus larval movement); PMC - primary motor center; MNs - motoneurons; LPNs - large paired neurons. Antigen positivity shown in this study is highlighted for each of the neuronal populations. More data are necessary to decipher the identity of Pax6 positive motoneurons in PMC. Scheme adapted after Lacalli (2008).

immunostainings (Fig. 3, Supplementary Fig. S1D). Two of the three sera (serum 393 and serum 394) labeled nuclear $\beta$-catenin at the blastula and mid-gastrula stage in the same pattern as the commercial anti-human $\beta$-catenin antibody. At mid-gastrula stage, both commercial and amphioxus-specific antibodies detected nuclear $\beta$-catenin throughout the mesendoderm (Fig. 3 A-Bii). At late blastula stage double immunostaining revealed asymmetrical distribution of nuclear $\beta$-catenin (Fig. $3 \mathrm{C}-\mathrm{Cii}$ ). The immunostaining with one of the sera (serum 097) did not show any specific pattern and, in contrast to the commercially available antibody, which labeled $\beta$-catenin throughout the mesendoderm at the mid-gastrula stage, detected nuclear $\beta$-catenin in all nuclei of the embryo (Supplementary Fig. S1D). It is of note that we observed a variable degree of staining for $\beta$-catenin to adherens junctions among individual embryos. This was the case for amphioxusspecific sera 393 and 394, as well as for commercial anti-human $\beta$-catenin antibody (Fig. 3, Supplementary Fig. S1D, and data not shown). The reason for inconsistent detection of $\beta$-catenin in adherens junctions is currently unclear. Combined, we not only generated functional antibody reagents against amphioxus $\beta$-catenin, but also validated the use of cross-reacting antibody originally developed against the human protein.
Next, we tested the usefulness of the newly generated homemade antibodies for high-resolution mapping of individual cells in the amphioxus larva. We performed double immunolabelling using mouse polyclonal antibody generated in this study and a commercial antibody made in another host to obtain single-cell resolution of specific neuronal populations in the cerebral vesicle (e.g. Row1 cells, primary motor centre, infundibular cells). This approach allowed a more precise characterization of individual neurons within the cerebral vesicle with respect to their anatomical position (Fig. 4), a task which is otherwise very difficult to perform. For example, to obtain similar results Lacalli and Candiani (2017) had to deduce their conclusion from a combination of data from in situ hybridization experiments and detailed electron microscopy analysis (analyses had to be, however, performed on larvae from different batches). By using the approach presented here, one can localize individual cell types within a single larva and easily obtain the information about their relative positions.

All immunostainings were initially performed on specimens fixed in $4 \%$ PFA for $15-45$ min on ice (alternatively at $4^{\circ} \mathrm{C}$ overnight). Fixed samples were subsequently transferred to $100 \%$ methanol and stored at $-20^{\circ} \mathrm{C}$ until use. For selected sera, we also tested the efficacy of immunostainings on embryos and larvae prepared 

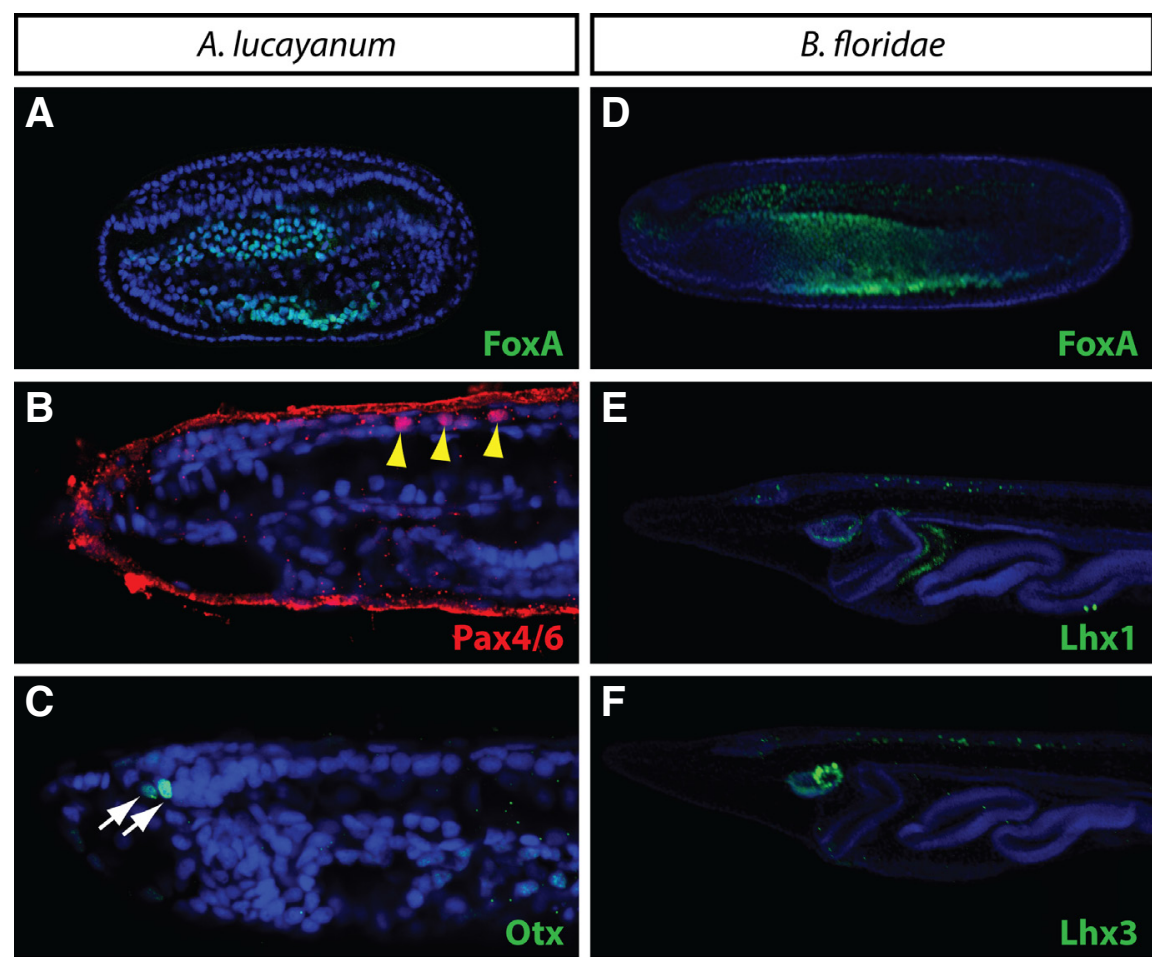

Fig. 5. Immunostaining of B. floridae and A. Iucayanum specimens. Embryos and larvae of A. lucayanum (A-C) and B. floridae (D-F) were immunostained with FoxA serum 326 (A,D) Pax6 serum 925 (B), Otx serum 72 (C), Lhx1 serum 249 (E) and Lhx3 serum 330 (F). The conspicuous ectodermal signal in (B) represents unspecific labelling.

for in situ hybridization (fixed in $4 \%$ PFA at $4^{\circ} \mathrm{C}$ overnight and stored in $70 \%$ ethanol). We found that some polyclonal antibodies are functional on such specimens making the logistic of embryo harvest simpler - the same sample can in principle be used for in situ hybridization and immunostaining (see Table 1).

We presume that an apparently high success rate of obtaining functional antibodies against amphioxus proteins by the procedure described here is largely due to sequence divergence of selected peptides between amphioxus and mice and choice of long peptide antigens. At the time of commencing the project, the complete genome sequence of $B$. floridae was available. Hence the antigens used in this study are of $B$. floridae origin but due to the high degree of sequence identity among different amphioxus species, we expected that most of the antibodies would allow cross-species detection. In general, interspecies cross-reactivity for home-made polyclonal antibodies was indeed observed (Table 1). All antibodies generated against $B$. floridae antigens, except for one, appear to be functional in detecting the corresponding orthologous protein in the European lancelet (B. lanceolatum). Some of the antibodies were even successfully validated in the more distantly related $A$. lucayanum (Fig. 5). However, in the case of Ops3 no positive immunostaining was observed in species other than the one from which the epitope was derived from, even though 45 out of 67 amino acids of the epitope were conserved (Supplementary Fig. S2). Combined, our data suggest that high degree of sequence identity typical for transcription factors and other regulatory proteins increases the likelihood of producing an antibody cross-reacting with proteins of different amphioxus species. We anticipate that in the near future the access to ge- nomes of individual lancelet species will allow cross-species homology analyses and a more rational choice of antigenic peptides with the aim of generating universal anti-amphioxus antibodies even for faster evolving genes, such as opsins.

\section{Conclusions}

We developed novel mouse polyclonal antibodies for use in immunostainings on amphioxus embryos. Our pilot study shows the feasibility of the experimental procedure that reliably yields functional antibodies at modest cost. Such antibodies can be used for elucidating embryonic gene expression at a single-cell resolution, for co-labelling using other antibodies or for investigating the sub-cellular localization of endogenous proteins in the developing embryo. Immunostaining can potentially be combined with WMISH (Lu et al., 2012) or transgenic fluorescent reporter proteins (Kozmikova and Kozmik, 2015), allowing double labeling of cell types or of embryological structures of interest. Polyclonal antibodies often allow detection of the same protein in different amphioxus species, such as B. floridae, B. lanceolatum and A. lucayanum. In summary, we anticipate that a panel of antibodies such as those generated by us here and by others in the future will represent a useful toolkit in amphioxus research.

\section{Materials and Methods}

\section{Generation of antibodies}

For overexpression of protein fragments, the $\mathrm{pET}$ system (Novagen) was used. Selected coding sequences were cloned into the pET42a(+) vector to create proteins containing $6 x$ His-GST fused to the protein fragment of interest. Amino acid sequences of antigens are shown in Supplementary Table 1. Expression vectors were introduced into the bacterial production strain of bacteria BL21 (DE3) RIPL (Stratagene). A total volume of 500 $\mathrm{ml}$ fresh LB medium without antibiotics was inoculated with an overnight culture grown in LB medium supplemented with $12.5 \mu \mathrm{g} / \mathrm{ml}$ chloramphenicol and $30 \mu \mathrm{g} / \mathrm{ml}$ kanamycin. Bacteria were grown at $37^{\circ} \mathrm{C}$ at 200 RPM until $\mathrm{OD}_{600}$ reached 0.6 , then induced by $0.5 \mathrm{mM}$ IPTG for 3 hours. Cells were harvested at $6000 \mathrm{xg}$ for 20 minutes and the pellet stored at $-80^{\circ} \mathrm{C}$ until further processing. The pellet was resuspended in Lysis buffer $\left(6 \mathrm{M}\right.$ guanidine hydrochloride, $0.1 \mathrm{M} \mathrm{NaH}_{2} \mathrm{PO}_{4}, 0.01 \mathrm{M}$ Tris. $\mathrm{Cl}, \mathrm{pH} 8.0$, supplemented with fresh $\beta$-mercaptoethanol to a final concentration of 20 $\mathrm{mM}$ ). The suspension was sonicated $6 \times 20 \mathrm{~s}$ and incubated for 3 hours at room temperature. The resulting lysate was centrifuged at $10,000 \times \mathrm{g}$ for 10 minutes and the supernatant mixed with Ni-NTA agarose beads (Qiagen) previously equilibrated with Urea buffer (8 M urea, $20 \mathrm{mM}$ Tris. $\mathrm{Cl}, 50 \mathrm{mM} \mathrm{NaH} \mathrm{PO}_{4}, 100 \mathrm{mM} \mathrm{NaCl}, \mathrm{pH}$ 8.0, supplemented with fresh $\beta$-mercaptoethanol to a final concentration of $20 \mathrm{mM}$ ). The suspension was incubated on a rotating platform overnight at room temperature. The beads with bound proteins were washed two times with $40 \mathrm{ml}$ Urea buffer and loaded onto a disposable chromatographic column (Bio-Rad). The column was washed with Urea buffer with decreasing $\mathrm{pH}(8.0-6.8)$ and His-tagged protein was eluted by Urea buffer at $\mathrm{pH} 4.2$ into several 1 $\mathrm{ml}$ aliquots. After elution, $\mathrm{pH}$ was immediately increased to 7.5 with $1 \mathrm{M}$ Tris. Cl, pH 8. Protein concentration was estimated using Protein Assay Reagent (Bio-Rad). Three mice of the B10A-H2xBALB/CJ strain were immunized four times in monthly intervals with $30 \mu \mathrm{g}$ purified protein mixed 
with Freund's Adjuvant (Sigma). An aliquot of serum was collected ten days after the $3^{\text {rd }}$ and $4^{\text {th }}$ immunization.

\section{Animal collection and immunohistochemistry}

B. lanceolatum adults were collected in Argeles-sur-Mer (France), transported to Institute of Molecular Genetics (Prague, Czech Republic) and preserved in the lab in a day/night cycle of $14 \mathrm{~h} / 10 \mathrm{~h}$ until spawning, which was induced by a shift in temperature (Fuentes et al., 2007). Adults of Florida amphioxus (B. floridae) were collected from Old Tampa Bay, Florida, during the summer breeding season. Adults were induced to spawn by electrostimulation as described (Yu and Holland, 2009). Ripe adults of A. lucayanum were collected in Bimini and allowed to spawn naturally in the laboratory (Holland and Holland, 2010). Embryos were raised in the laboratory on site. Embryos for immunohistochemistry were fixed with 4\% PFA/MOPS (0.1 M 3-(N-morpholino)propanesulfonic acid, $2 \mathrm{mM} \mathrm{MgSO}$, $1 \mathrm{mM} \mathrm{EGTA}, 0.5 \mathrm{M} \mathrm{NaCl}, \mathrm{pH} 7.5$ ) for 15 minutes on ice and stored in $100 \%$ methanol. Some specimens were fixed with $4 \%$ PFA/MOPS overnight at $4^{\circ} \mathrm{C}$ and stored in $70 \% \mathrm{EtOH}$. Specimens were transferred to $1 \times \mathrm{PBS}$ $0.1 \%$ Tween-20 (PBT) through $70 \%$ and $30 \%$ methanol in PBS. Following four 15-minute washes in PBT, samples were blocked in blocking solution (10\% BSA in PBT) for (at least) $1 \mathrm{~h}$ and incubated with primary antibodies overnight at $4^{\circ} \mathrm{C}$. Amphioxus-specific antibodies were diluted 1:200 to $1: 500$ in blocking solution. The following commercial primary antibodies were used: $\beta$-catenin (Sigma C2206, rabbit polyclonal, dilution 1:500), GABA (Sigma A2052, rabbit polyclonal, 1:500), tyrosine hydroxylase (TH, Abcam ab112, rabbit polyclonal, 1:1000), glutamate (Sigma G6642, rabbit polyclonal, 1:500), serotonin (Abcam ab66047, goat polyclonal, $1: 1000)$. On the following day, samples were washed five times in PBT (20 minutes each wash) and were incubated with secondary antibodies and $1 \mu \mathrm{g} / \mathrm{mL}$ DAPI for 3 hours at room temperature. Alexa Fluor 488 or 594 anti-mouse, anti-rabbit or anti-goat were used as secondary antibody at 1:500 dilution. For confocal microscopy, the samples were mounted in VECTASHIELD (Vector Laboratories, Inc.) using three layers of Scotch tape as spacers between the slide and the coverslip. The confocal images were taken using a Leica SP5 or SP8 confocal microscope and were processed (brightness and contrast) with FIJI image analysis software. Images were further processed (rotation) and assembled in tables with Adobe Photoshop CS4.

\section{Acknowledgements}

This work was funded by the Czech Science Foundation (15-21285J to IK). We acknowledge the Microscopy Centre - Light Microscopy Core Facility, IMGASCR, Prague, Czech Republic, supported by grants (CzechBioimaging - MEYS LM2015062), "Centre of Model Organisms" OPPK (CZ.2.16/3.1.00/21547) and "Biomodels for health" (LO1419), for their support with the confocal imaging presented herein. We are indebted to Hector Escriva and Stephanie Bertrand from OOB in Banyuls-sur-Mer, France, for providing Branchiostoma lanceolatum adults and to Nicholas Holland for help in collecting adults of Branchiostoma floridae and Asymmetron lucayanum. We are grateful to Jitka Lachova, Veronika Noskova, Veronika Kovacsova and Vladimir Soukup for technical assistance and Sarka Takacova for proofreading.

\section{References}

ACEMEL, R.D., TENA, J.J., IRASTORZA-AZCARATE, I., MARLETAZ, F., GOMEZMARIN, C., DE LACALLE-MUSTIENES, E., BERTRAND, S., DIAZ, S.G., ALDEA D., AURY, J.M. et al., (2016). A single three-dimensional chromatin compartment in amphioxus indicates a stepwise evolution of vertebrate Hox bimodal regulation. Nat Genet 48: 336-341.

BERTRAND, S. and ESCRIVA, H. (2011). Evolutionary crossroads in developmental biology: amphioxus. Development 138: 4819-4830.

FUENTES, M., BENITO, E., BERTRAND, S., PARIS, M., MIGNARDOT, A., GODOY, L., JIMENEZ-DELGADO, S., OLIVERI, D., CANDIANI, S., HIRSINGER, E. et al., (2007). Insights into spawning behavior and development of the European am- phioxus (Branchiostoma lanceolatum). J Exp Zool B Mol Dev Evol308: 484-493.

GLARDON, S., HOLLAND, L.Z., GEHRING, W.J. and HOLLAND, N.D. (1998). Isolation and developmental expression of the amphioxus Pax-6 gene (AmphiPax-6): insights into eye and photoreceptor evolution. Development 125: 2701-2710.

HOLLAND, L.Z., ALBALAT, R., AZUMI, K., BENITO-GUTIERREZ, E., BLOW, M.J., BRONNER-FRASER, M., BRUNET, F., BUTTS, T., CANDIANI, S., DISHAW, L.J. et al., (2008). The amphioxus genome illuminates vertebrate origins and cephalochordate biology. Genome Res 18: 1100-1111.

HOLLAND, L.Z., PANFILIO, K.A., CHASTAIN, R., SCHUBERT, M. and HOLLAND, N.D. (2005). Nuclear beta-catenin promotes non-neural ectoderm and posterior cell fates in amphioxus embryos. Dev Dyn 233: 1430-1443.

HOLLAND, N.D. and HOLLAND, L.Z. (2010). Laboratory spawning and development of the Bahama lancelet, Asymmetron lucayanum (cephalochordata): fertilization through feeding larvae. Biol Bull 219: 132-141.

HUANG, S., CHEN, Z., YAN, X., YU, T., HUANG, G., YAN, Q., PONTAROTTI, P.A., ZHAO, H., LI, J., YANG, P. et al., (2014). Decelerated genome evolution in modern vertebrates revealed by analysis of multiple lancelet genomes. Nat Commun 5: 5896

IGAWA, T., NOZAWA, M., SUZUKI, D.G., REIMER, J.D., MOROV, A.R., WANG, Y., HENMI, Y. and YASUI, K. (2017). Evolutionary history of the extant amphioxus lineage with shallow-branching diversification. Sci Rep 7: 1157.

KOZMIK, Z., HOLLAND, N.D., KRESLOVA, J., OLIVERI, D., SCHUBERT, M., JONASOVA, K., HOLLAND, L.Z., PESTARINO, M., BENES, V. and CANDIANI, S. (2007). Pax-Six-Eya-Dach network during amphioxus development: conservation in vitro but context specificity in vivo. Dev Biol 306: 143-159.

KOZMIKOVA, I. and KOZMIK, Z. (2015). Gene regulation in amphioxus: An insight from transgenic studies in amphioxus and vertebrates. Mar Genomics 24 Pt 2 : 159-166.

LACALLI, T. and CANDIANI, S. (2017). Locomotory control in amphioxus larvae: new insights from neurotransmitter data. Evodevo 8: 4.

LACALLI, T.C. (2008). Basic features of the ancestral chordate brain: a protochordate perspective. Brain Res Bull 75: 319-323.

LANGELAND, J.A., HOLLAND, L.Z., CHASTAIN, R.A. and HOLLAND, N.D. (2006). An amphioxus LIM-homeobox gene, AmphiLim1/5, expressed early in the invaginating organizer region and later in differentiating cells of the kidney and central nervous system. Int J Biol Sci 2: 110-116.

LE PETILLON, Y., LUXARDI, G., SCERBO, P., CIBOIS, M., LEON, A., SUBIRANA L., IRIMIA, M., KODJABACHIAN, L., ESCRIVA, H. and BERTRAND, S. (2017). Nodal/Activin Pathway is a Conserved Neural Induction Signal in Chordates. Nat Ecol Evol 1: 1192-1200.

LI, G., LIU, X., XING, C., ZHANG, H., SHIMELD, S.M. and WANG, Y. (2017). Cerberus-Nodal-Lefty-Pitx signaling cascade controls left-right asymmetry in amphioxus. Proc Natl Acad Sci USA 114: 3684-3689.

LU, T.M., LUO, Y.J. and YU, J.K. (2012). BMP and Delta/Notch signaling control the development of amphioxus epidermal sensory neurons: insights into the evolution of the peripheral sensory system. Development 139: 2020-2030.

PUTNAM, N.H., BUTTS, T., FERRIER, D.E., FURLONG, R.F., HELLSTEN, U. KAWASHIMA, T., ROBINSON-RECHAVI, M., SHOGUCHI, E., TERRY, A., YU, J.K. et al., (2008). The amphioxus genome and the evolution of the chordate karyotype. Nature 453: 1064-1071.

SHIMELD, S.M. (1997). Characterisation of amphioxus HNF-3 genes: conserved expression in the notochord and floor plate. Dev Biol 183: 74-85.

SOMORJAI, I., BERTRAND, S., CAMASSES, A., HAGUENAUER, A. and ESCRIVA $H$. (2008). Evidence for stasis and not genetic piracy in developmental expression patterns of Branchiostoma lanceolatum and Branchiostoma floridae, two amphioxus species that have evolved independently over the course of $200 \mathrm{Myr}$. Dev Genes Evol 218: 703-713.

SOUKUP, V., YONG, L.W., LU, T.M., HUANG, S.W., KOZMIK, Z. and YU, J.K. (2015). The Nodal signaling pathway controls left-right asymmetric development in amphioxus. Evodevo 6: 5.

TERAZAWA, K. and SATOH, N. (1997). Formation of the chordamesoderm in the amphioxus embryo: Analysis with Brachyury and fork head/HNF-3 genes. Dev Genes Evol 207: 1-11.

VOPALENSKY, P., PERGNER, J., LIEGERTOVA, M., BENITO-GUTIERREZ, E., ARENDT, D. and KOZMIK, Z. (2012). Molecular analysis of the amphioxus 
frontal eye unravels the evolutionary origin of the retina and pigment cells of the vertebrate eye. Proc Natl Acad Sci USA 109: 15383-15388.

WANG, Y., ZHANG, P.J., YASUI, K. and SAIGA, H. (2002). Expression of Bblhx3, a LIM-homeobox gene, in the development of amphioxus Branchiostoma belcheri tsingtauense. Mech Dev 117: 315-319.

WU, H.R., CHEN, Y.T., SU, Y.H., LUO, Y.J., HOLLAND, L.Z. and YU, J.K. (2011). Asymmetric localization of germline markers Vasa and Nanos during early development in the amphioxus Branchiostoma floridae. Dev Biol 353: 147-159.

YASUI, K., LI, G., WANG, Y., SAIGA, H., ZHANG, P. and AIZAWA, S. (2002). betaCatenin in early development of the lancelet embryo indicates specific determi- nation of embryonic polarity. Dev Growth Differ 44: 467-475.

YU, J.K. and HOLLAND, L.Z. (2009). Amphioxus (Branchiostoma floridae) spawning and embryo collection. Cold Spring Harb Protoc 2009: pdb prot5285.

YUE, J.X., KOZMIKOVA, I., ONO, H., NOSSA, C.W., KOZMIK, Z., PUTNAM, N.H. YU, J.K. and HOLLAND, L.Z. (2016). Conserved Noncoding Elements in the Most Distant Genera of Cephalochordates: The Goldilocks Principle. Genome Biol Evol 8: 2387-2405.

YUE, J.X., YU, J.K., PUTNAM, N.H. and HOLLAND, L.Z. (2014). The transcriptome of an amphioxus, Asymmetron lucayanum, from the Bahamas: a window into chordate evolution. Genome Biol Evol 6: 2681-2696. 


\section{Further Related Reading, published previously in the Int. J. Dev. Biol.}

From the American to the European amphioxus: towards experimental Evo-Devo at the origin of chordates Jordi Garcia-Fernàndez, Senda Jiménez-Delgado, Juan Pascual-Anaya, Ignacio Maeso, Manuel Irimia, Carolina Minguillón, Èlia BenitoGutiérrez, Josep Gardenyes, Stéphanie Bertrand and Salvatore D’Aniello Int. J. Dev. Biol. (2009) 53: 1359-1366 https://doi.org/10.1387/ijdb.072436jg

The amphioxus genome in Evo-Devo: archetype or "cul de sac'? J Garcia-Fernandez, DEK Ferrier, C Minguillon, C Cebrian Int. J. Dev. Biol. (2001) 45: S137-S138

Cell morphology in amphioxus nerve cord may reflect the time course of cell differentiation T C Lacalli

Int. J. Dev. Biol. (2000) 44: 903-906

http://www.intjdevbiol.com/web/paper/11206331

Embryonic development of heads, skeletons and amphioxus: Edwin S. Goodrich revisited P W Holland

Int. J. Dev. Biol. (2000) 44: 29-34

http://www.intjdevbiol.com/web/paper/10761843

Amphioxus Hox genes: insights into evolution and development

$\mathrm{J}$ Garcia-Fernàndez and $\mathrm{P}$ W Holland

Int. J. Dev. Biol. (1996) 40: S71-S72

http://www.intjdevbiol.com/web/paper/9087701

5 yr ISI Impact Factor $(2013)=2.879$
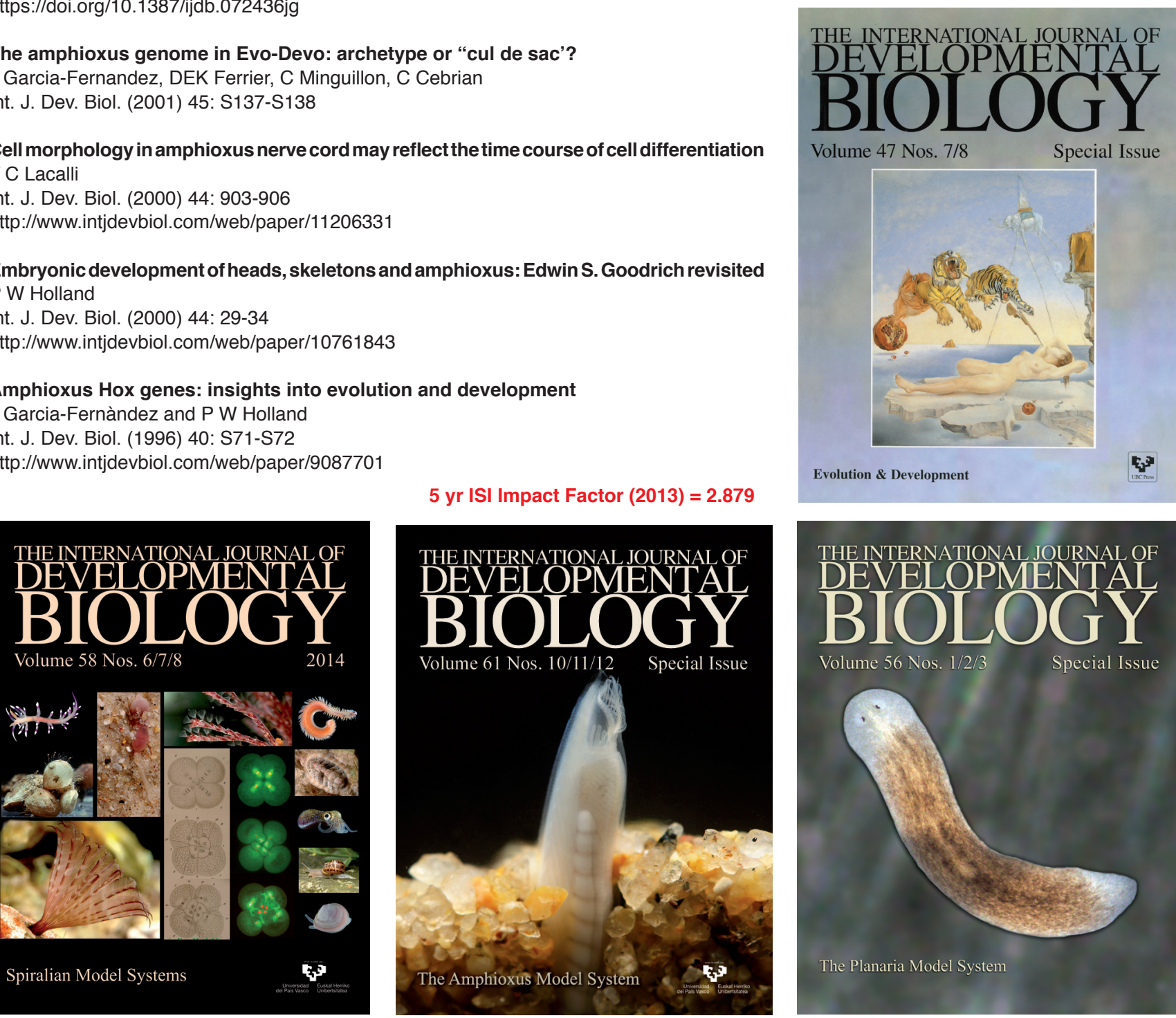